\title{
KANDUNGAN NITROGEN, PHOSPOR, KALIUM DAN SULFUR PADA PUPUK ORGANIK CAIR (POC) KOTORAN SAPI SETELAH MELALUI PROSES DIGESTER DI DESA TAMANAN KECAMATAN SUKOMORO KABUPATEN MAGETAN
}

\author{
Renik Wijianti, Beny Suyanto, Sujangi
}

\begin{abstract}
ABSTRAK
Treatment of cattle wastes is one effort that is quite beneficial and can reduce the negative impacts on the environment. One way of utilizing livestock manures or organic materials is through the use of biogas. This is rather appropriate since majority of the population reside in rural areas. Meanwhile, the waste generated out of the biogas digester can be used as liquid organic fertilizer (LOF) with high nutrient contents suitable for plants.

This experimental study was aimed to determine the content of nitrogen ( $N$ ), phosphorus ( $P$ ), potassium ( $K$ ), and sulphur ( $S$ ) as a Liquid Organic fertilizer ( LOF ). This investigation was run using one group pretest posttest design. Raw cow dung was processed in biogas digesters ( $\max 3 \mathrm{~m}^{3}$ ) with detention time $\left(t_{d}\right)$ of 7 days, 14 days and 21 days, and the content of $N, P, K, S$ will be measured before and after the process in the digester.

In the examination before the process, the $\mathrm{N}$ content $(0.10 \%), \mathrm{P}$ content $(1.13 \%)$, content of $\mathrm{K}(0.59$ $\%$ ) content of S ( $1.19 \%$ ). After the 7,14 and 21 days the $\mathrm{N}$ content increased from its original state. The highest increment was at day 21 , with a large increase of ( $41.2 \%$ ). The element $P$ ( td ) 7,14 and 21 days have shown a continuous decline and the highest was on day 21 that reached ( $30.08 \%$ ). For elements of $K$ and $S$ for ( $t d$ ) 7,14 and 21 days have continuously increased. The highest generation rate of the element $K$ on day 21 reached $(15.7 \%$ ) and $S$ reached ( $43.6 \%$ ). It appeared that the longer the process in the digester, the $\mathrm{N}, \mathrm{K}$ and $\mathrm{S}$ contents is increasing although it remained below the standard designated in Permentan 28 / Permentan / OT.140/2/2009. While the P element on the contrary was decreasing and there were indications of the longer the process in the digester the greater the decline. This indicated that the P element much needed by the bacteria in the fermentation process.

An increase in the content of N, K and S as a nutrient for plant growth as generated by the biogas digester using raw manure in this study have met the LOF requirements. Effectiveness in improving $N, P, K$ and $S$ contents required further research on the type of starter bacteria to be used, duration of the process ( $t d$ ) and the ratio of water and cow dung in order to obtain the most effective and efficient results.
\end{abstract}

Keywords : cow manure, biogas digesters, NPKS content

\section{PENDAHULUAN}

Pengolahan limbah ternak merupakan salah satu upaya yang memberi banyak manfaat. Pada satu sisi, pengolahan limbah ternak dapat mengurangi dampak terhadap lingkungan. Disisi lain, pengolahan limbah memberikan keuntungan finansial karena pengolahannya menghasilkan produk yang mempunyai daya jual. Limbah ternak merupakan sisa buangan dari kegiatan usaha pemeliharaan ternak yang berupa limbah padat dan cair. (AnneAhira.com Content Ream, 2012)

Untuk memanfaatkan kotoran ternak atau bahan organik lainnya agar dapat digunakan seoptimal mungkin, sehingga tidak menjadi bahan pencemarmelainkan menjadi inti dari mitra usaha peternakan dan pengembangannya. Dalam penggunaan bahan bakar alternative dan biogas merupakan salah satu bahan pilihan alternative masa depan bagi masyarakat Indonesia yang mayoritas tinggal di pedesaan. Oleh karena itu masyarakat dapat menyediakan energi rumah tangganya dengan membuat biogas dengan bahan baku yang berupa Kotoran Sapi.(Anis Fahri, 2009)

\begin{abstract}
Peranan pemerintah pengembangan energi alternatif dari biogas dapat menciptakan lapangan kerja baru masyarakat. Adanya instalasi biogas dan hasil sampingannya dapat memberda ya kan sumber daya manusia yang berpendidikan menengah untuk diberdayakan secara optimal. Keluaran dari digester biogas yang diolah menjadi pupuk organik memberikan dua keuntungan sekaligus. Pertama, terciptanya lapangan kerja dan yang kedua dihasilkannya benefit dari penjualan pupuk organik. (Sri Wahyuni, 2009)
\end{abstract}

Pupuk organik merupakan pupuk dengan bahan dasar yang diambil dari alam dengan jumlah dan jenis unsur hara yang terkandung secara alami. Pupuk organik merupakan salah satu bahan yang sangat penting dalam upaya memperbaiki kesuburan tanah secara aman, dalam artian aman terhadap pencemaran lingkungan serta produk pertanian yang dihasilkan terbebas dari bahan-bahan kimia yang berbahaya bagi lingkungan dan kesehatan manusia sehingga aman dan sehat dikonsumsi.

Digester adalah bangunan ruangan (tandon) sebagai tangki pencerna untuk memproses limbah organik misalnya kotoran 
sapi, air kencing dan air, sebagai tempat bakteri anaerob menguraikan limbah isian tersebut selama waktu tertentu. Dari proses fermentasi limbah tersebut akan menghasilkan gas bio, serta slurry (sisa keluaran setelah di proses sebagai pupuk organik) yang siap pakai dengan unsur hara yang tinggi. (Lutjito, 2008)

Dari proses produksi digester biogas akan dihasilkan limbah atau sisa bahan organik. Limbah dari digester biogas tersebut ternyata memiliki nilai manfaat yang cukup tinggi, yaitu dapat dijadikan sebagai pupuk organik. Bahkan pupuk tersebut dapat langsung digunakan untuk memupuk tanaman. (Sri Wahyuni, 2009)

Tujuan penelitian ini adalah mengetahui efektifitas digester biogas dari kotoran sapi pada waktu tinggal (td) 7 hari, 14 hari, dan 21 hari, dengan mengukur kandungan $N, P, K, S$ sebelum dan sesudah proses digester

\section{METODE PENELITIAN}

Penelitian ini menggunakan rancangan penelitian one group pre and post test design, dimana peneliti melakukan pengukuran sebelum dan sesudah perlakuan kemudian hasil kedua pengukuran (Nitrogen, Phospor, Kalium dan Sulfur) tersebut dibandingkan untuk melihat perbedaan tingkat kemampuan Kotoran Sapi. Analisis yang digunakan adalah analisis deskriptif yakni membahas perbedaan kandungan NPKS sebelum dan sesudah perlakuan 7 hari, 14 hari dan 21 hari dari hasil pemeriksaan laboratorium yang disajikan dalam bentuk tabel.

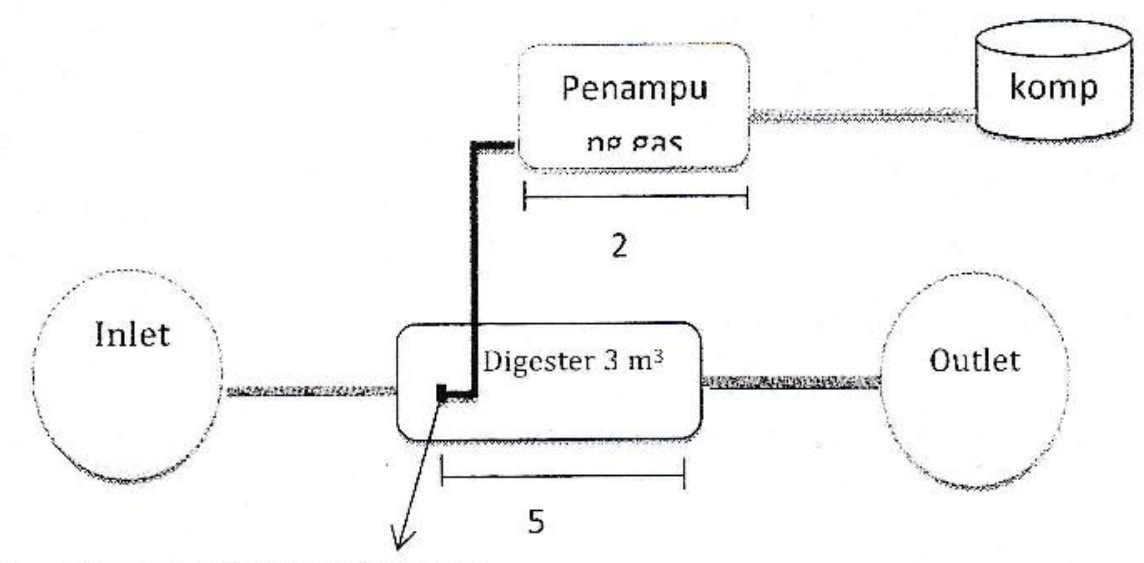

Pipa PVC (shock drat dalam dan

\section{Gambar 1: Sketsa proses biogas}

\section{HASIL PENELITIAN DAN PEMBAHASAN}

\section{Hasil Pemeriksaan Laboratorium}

Dari hasil pengukuran Pupuk Organik Cair (POC) sebelum dan setelah perlakuan 7 hari, 14 hari dan 21 hari menunjukkan bahwa Nitrogen dalam $\mathrm{N}$ Total (\%) menunjukkan ada kenaikan. Kandungan Phospor (\%) ada penurunan Sedangkan kandungan Kalium (\%) dan Sulfur (\%) ada kenaikan.

Tabel 1: Hasil pengukuran kandungan Pupuk Organik Cair (POC) sebelum dan setelah perlakuan

\begin{tabular}{|c|c|c|c|c|c|}
\hline No & K O D E & $\begin{array}{c}\mathbf{N} \\
(\mathbf{\%})\end{array}$ & $\begin{array}{c}\mathbf{P} \\
(\mathbf{\%})\end{array}$ & $\begin{array}{c}\mathbf{K} \\
(\%)\end{array}$ & $\begin{array}{c}\mathbf{S} \\
(\mathbf{\%})\end{array}$ \\
\hline 1 & A & 0.10 & 1.13 & 0,59 & 1,19 \\
\hline 2 & B & 0.11 & 0.99 & 0,59 & 1,37 \\
\hline 3 & C & 0.14 & 0.84 & 0,62 & 1,95 \\
\hline 4 & D & 0.17 & 0.79 & 0,70 & 2,11 \\
\hline
\end{tabular}

Data primer : Hasil Pemeriksaan laboratorium Fakultas Pertanian UNS Surakarta

Keterangan :

Kode $A=$ Sebelum perlakuan

Kode $\mathrm{B}=$ Setelah perlakuan 7 hari

Kode $C=$ Setelah perlakuan 14 hari

Kode $D=$ Setelah perlakuan 21 hari 


\section{Karakteristik fisik POC dari bahan kotoran sapi}

1) Tekstur kotoran sapi sebelum perlakuan coklat kehijauan dan setelah perlakuan 7 hari menunjukkan tekstur hampir sama, setelah perlakuan 14 hari tekstur sedikit berubah. Setelah 21 hari tekstur berubah menjadi coklat tua. Hal ini menunjukkan bahwa proses fermentasi berlangsung dan mendekati pematangan. Gas yang ada di dalam kotoran sapi dan air telah tertampung dalam penampungan gas dan POC dapat digunakan langsung untuk pemberian unsur hara pada tanaman.

2) Baularutan kotoran sapi dan air sebelum dimasukkan dalam digester berbau menyengat khas kotoran sapi. Setelah perlakuan 7 hari bau tersebut sedikit berkurang. Begitu juga setelah perlakuan 14 hari dan 21 hari menunjukkan bau khas kotoran sapi semakin berkurang. Dengan demikian menunjukkan bahwa semakin lama proses fermentasi dalam digester menunjukkan bau khas kotoran sapi semakin berkurang.

\section{Hasil pemeriksaan Pupuk organik (POC) sebelum dan setelah perlakukan 7 hari.}

Untuk mengetahui efisiensi proses digester, kandungan Pupuk (POC) sebelum dan setelah perlakukan 7 hari hasil perhitungan tercantum dalam tabel berikut ini :

Tabel 2: Hasil Pemeriksaan Pupuk Organik Cair (POC) sebelum dan setelah perlakuan7 hari

\begin{tabular}{|c|c|c|c|c|c|c|c|c|}
\hline \multirow[b]{2}{*}{ No } & \multirow{2}{*}{$\begin{array}{c}\text { Penguji } \\
\text { an } \\
\text { bahan } \\
\text { POC }\end{array}$} & \multicolumn{2}{|c|}{ Kadar } & \multirow{2}{*}{$\begin{array}{l}\text { Tk } \\
\text { Kenaik } \\
\text { an } \\
\text { Kadar }\end{array}$} & \multirow{2}{*}{$\begin{array}{c}\text { TK } \\
\text { Penurun } \\
\text { an } \\
\text { Kadar }\end{array}$} & \multicolumn{2}{|c|}{ Efisiensi(\%) } & \multirow{2}{*}{$\begin{array}{c}\text { PerMenTan } \\
\text { No.28/Per } \\
\text { mentan/ } \\
\text { OT.140/ } \\
\text { 2/2009 }\end{array}$} \\
\hline & & $\begin{array}{c}\text { Sebelum } \\
\text { perlaku } \\
\text { an }\end{array}$ & $\begin{array}{l}\text { Setelah } \\
\text { perlaku } \\
\text { an } 7 \mathrm{hr}\end{array}$ & & & $\begin{array}{c}\text { Kenaik } \\
\text { an } \\
\text { Kadar }\end{array}$ & $\begin{array}{c}\text { Penurun } \\
\text { an } \\
\text { Kadar }\end{array}$ & \\
\hline A & B & C & D & $E$ & $\mathrm{~F}$ & G & $\mathrm{H}$ & I \\
\hline 1 & $\begin{array}{l}\text { N Total } \\
(\%)\end{array}$ & 0,10 & 0,11 & 0,01 & - & 9,09 & - & $<2$ \\
\hline 2 & $P(\%)$ & 1,13 & 0,99 & $\begin{array}{ll}- & - \\
\end{array}$ & 0,14 & - & 12,389 & $<2$ \\
\hline 3 & K (\%) & 0,59 & 0,59 & - & - & 0 & 0 & $<2$ \\
\hline 4 & $\mathrm{~S}(\%)$ & 1,19 & 1,37 & 0,18 & - & 13,14 & - & - \\
\hline
\end{tabular}

Keterangan :
$E=D-C$
$F=C-D$
$\mathrm{G}=\frac{\mathrm{D}-\mathrm{C}}{\mathrm{D}} \times 100 \%$
$H=\frac{C-D}{C} \times 100 \%$

Hasil Pemeriksaan Pupuk organik (POC) sebelum dan setelah perlakukan 14 hari.

Dari hasil pengukuran Pupuk Organik Cair (POC) sebelum dan sesudah perlakuan 14 hari Kandungan $\mathrm{N}, \mathrm{K}, \mathrm{S}$ ada kenaikan sedangkan $\mathrm{P}$ mengalami penurunan. Fermentasi oleh bakteri dalam digester menghasilkan $\mathrm{N}, \mathrm{K}, \mathrm{S}$ dan memerlukan P. Ada indikasi bertambahnya unsur $\mathrm{N}, \mathrm{K}, \mathrm{S}$ merubah tekstur warna limbah dan berkurangnya bau. Besarnya kadar Nitrogen ( $\mathrm{N}$ Total) menunjukkan ada kenaikan sebesar $28,571 \%$. Kadar Phospor (P) menunjukkan ada penurunan sebesar $25,664 \%$. Kadar Kalium (K) menunjukkan ada kenaikan 4,839 \% sedangkan kadar Sulfur (S) menunjukkan ada kenaikan $38,974 \%$. 
Tabel 3: Hasil Pemeriksaan Pupuk Organik Cair (POC) sebelum dan setelah perlakuan 14 hari

\begin{tabular}{|c|c|c|c|c|c|c|c|c|}
\hline \multirow{2}{*}{ No } & \multirow[b]{2}{*}{$\begin{array}{c}\text { Peng } \\
\text { ujian } \\
\text { bahan } \\
\text { POC }\end{array}$} & \multicolumn{2}{|c|}{ Kadar } & \multirow{2}{*}{$\begin{array}{c}\text { Tk } \\
\text { Kenaik } \\
\text { an } \\
\text { Kadar }\end{array}$} & \multirow{2}{*}{$\begin{array}{c}\text { TkPe } \\
\text { Nurun } \\
\text { an } \\
\text { Kadar }\end{array}$} & \multicolumn{2}{|c|}{$\begin{array}{c}\text { Efisiensi } \\
(\%)\end{array}$} & \multirow[b]{2}{*}{$\begin{array}{c}\text { PerMenTan } \\
\text { No.28/ } \\
\text { Permentan } \\
\text { OT.140/2/ } \\
2009\end{array}$} \\
\hline & & $\begin{array}{c}\text { Se } \\
\text { belum } \\
\text { perlaku } \\
\text { an }\end{array}$ & $\begin{array}{c}\text { Stih } \\
\text { perlaku } \\
\text { an } \\
14 \text { hari }\end{array}$ & & & $\begin{array}{c}\text { Kenaik } \\
\text { an } \\
\text { Kadar }\end{array}$ & $\begin{array}{c}\text { Penurun } \\
\text { an } \\
\text { Kadar }\end{array}$ & \\
\hline A & B & C & D & $E$ & $\mathrm{~F}$ & G & $\mathrm{H}$ & I \\
\hline 1 & $N(\%)$ & 0,10 & 0,14 & 0,04 & - & 28,571 & - & $<2$ \\
\hline 2 & $\mathrm{P}(\%)$ & 1,13 & 0,84 & - & 0,29 & - & 25,664 & $<2$ \\
\hline 3 & K (\%) & 0,59 & 0,62 & 0,03 & - & 4,839 & - & $<2$ \\
\hline 4 & S(\%) & 1,19 & 1,95 & 0,76 & - & 38,974 & - & - \\
\hline
\end{tabular}

\section{Hasil pemeriksaan Pupuk organik (POC) setelah perlakukan 21 hari.}

Kadar N, K, dan S perlakuan 21 hari (td) meningkat sedangkan $\mathrm{P}$ ada penurunan. Waktu perlakuan 21 hari merupakan waktu yang paling baik dari pada 7 dan 14 hari. Hal ini ditunjukan ada perubahan tekstur warna dan hilangnya bau yang menyengat. Peningkatan $\mathrm{N}, \mathrm{K}, \mathrm{S}$ berturutturut yaitusebesar : $41,176 \% ; 15,714 \% ; 43,6 \%$ dan $P$ menunjukkan ada penuFunan $30,088 \%$. Penurunan $\mathrm{P}$ ada indikasi semakin lama proses dalam digester penurunan semakin besar.

Tabel 4: Hasil Pemeriksaan Pupuk Organik Cair (POC) sebelum dan setelah perlakuan 21 hari

\begin{tabular}{|c|c|c|c|c|c|c|c|c|}
\hline \multirow{2}{*}{ No } & \multirow[b]{2}{*}{$\begin{array}{c}\text { Penguji } \\
\text { an } \\
\text { bahan } \\
\text { POC }\end{array}$} & \multicolumn{2}{|c|}{ Kadar } & \multirow{2}{*}{$\begin{array}{l}\text { Tk Ke } \\
\text { Naik } \\
\text { an } \\
\text { Kadar }\end{array}$} & \multirow{2}{*}{$\begin{array}{c}\text { Tk Pe } \\
\text { Nurun } \\
\text { an } \\
\text { Kadar }\end{array}$} & \multicolumn{2}{|c|}{ Efisiensi (\%) } & \multirow[b]{2}{*}{$\begin{array}{c}\text { PerMenTan } \\
\text { No. } 28 / \text { Per } \\
\text { mentan/ } \\
\text { OT.140/2/ } \\
2009\end{array}$} \\
\hline & & $\begin{array}{l}\text { Seblm } \\
\text { per } \\
\text { Laku } \\
\text { an }\end{array}$ & $\begin{array}{c}\text { Setelah } \\
\text { perlaku } \\
\text { an } \\
14 \text { hari }\end{array}$ & & & $\begin{array}{l}\text { Ke } \\
\text { naik } \\
\text { an } \\
\text { Kadar }\end{array}$ & $\begin{array}{l}\text { Pe } \\
\text { nurun } \\
\text { an } \\
\text { Kadar }\end{array}$ & \\
\hline A & $B$ & C & D & $\mathrm{E}$ & $F$ & G & $\mathrm{H}$ & I \\
\hline 1 & $\begin{array}{l}\text { N Total } \\
(\%)\end{array}$ & 0,10 & 0,17 & 0,07 & - & 41,176 & - & $<2$ \\
\hline 2 & $\mathrm{P}(\%)$ & 1,13 & 0,79 & - & 0,34 & - & 30,088 & $<2$ \\
\hline 3 & $\mathrm{~K}(\%)$ & 0,59 & 0,70 & 0,11 & - & 15,714 & - & $<2$ \\
\hline 4 & S(\%) & 1,19 & 2,11 & 0,92 & - & 43,6 & - & - \\
\hline & $\begin{array}{l}\text { terangan } \\
=D-C \\
=C-D\end{array}$ & & $=\frac{D-C}{D} X$ & & & $100 \%$ & & \\
\hline
\end{tabular}

\section{SIMPULAN}

Semakin lama proses dalam digester ada indikasi kenaikan kandungan unsur N,K dan S tersebut, walaupun masih di bawah Permentan No.28/Permentan/OT.140/2/2009. Sedangkan unsur $\mathrm{P}$ justru terjadi sebaliknya yaitu mengalami penurunan. Hal ini menunjukan bahwa unsur $P$ dalam proses fermentasi, banyak dibutuhkan oleh bakteri.

Peningkatan kandungan unsur $\mathrm{N}, \mathrm{K}$ dan $\mathrm{S}$ sebagai unsur hara dalam tanaman dari proses digester biogas dengan bahan baku kotoran sapi dalam penelitian ini memenuhi syarat POC. 


\section{Saran.}

Untuk mendapatkan tingkat efektifitas dalam meningkatkan unsur $\mathrm{N}, \mathrm{P}, \mathrm{K}$ dan $\mathrm{S}$ diperlukan penelitian lebih lanjut tentang starter

\section{DAFTAR ACUAN}

Karno et al, 2013, Biogas itu murah dan mudah, Politeknik Kesehatan Kemenkes Surabaya, Kementerian Kesehatan RI

Sri Wahyuni, 2009, Biogas, Penebar Swadaya

Mochammad Junus, 1995. Teknik Pembuatan dan Memanfaatkan Unit Gas Bio, Fakultas Peternakan Universitas Brawijaya

Sugi Rahayu, et al 2008, Pemanfaatan Kotoran Ternak Sapi Sebagai Sumber Energi Alternatif Ramah Lingkungan Beserta Aspek Sosio Kuituralny

Anis Fahri, 2009, Teknik Pembuatan Biogas dari Kotoran Ternak

Widodo, 2006, Pemanfaatan Limbah Kotoran Ternak Sapi Sebagai Energi Alternatif (Biogas) Skala Rumah Tangga Yang Ramah Lingkungan

Peternakan Kita, 2012, Pembuatan Dan Pemanfaatan Biogas Sebagai Energi Alternatif Dengan Menggunakan Tabung Digester Metode Kultur Kontinyu jenis bakteri yang digunakan, lama proses (td) dan perbandingan air dan kotoran sapi agar diperoleh manfaat yang cukup efisien.

Zhang et al, 1997, Biogas dari Limbah Organik Soeparman, 2002, 2006, Balai Besar Litbang Sumber Daya Lahan Pertanian Pupuk Biogas http://id.wikipedia.org/wiki/Pupuk

http://www.petra.ac.id/science/applied technology/biogas98/biogas.htm

http://widyatan.com/index/pemanfatan-limbahternak-sebagai-sumber-pupuk organik

http://tabloidjubi.wordpress.com/2008/05/07/kot oran-ternak-antara-polusi lingkungan-dansumber-energi-alternatif/

http://www.tanijogonegoro.com/2012/12/defisie nsi-unsur-hara.htm!

http://www.pilarlima.com/index.php/tipsinformasi/28-pengertian-macam macampupuk-organik-dan-anorganik 